\title{
PEMBERDAYAAN ANGGOTA PERSATUAN ISTERI PRAJURIT (PERSIT) DALAM MENINGKATKAN KEMANDIRIAN MELALUI PROGRAM POS PELAYANAN TERPADU (POSYANDU) DI BRIGADE INFANTERI 15 KUJANG II CIMAHI
}

\author{
${ }^{1)}$ Anita Rakhman, ${ }^{2}$ Prita Kartika \\ ${ }^{1)}$ anitarakhman@yahoo.com, ${ }^{2}$ kartika@ stkipsiliwangi.ac.id \\ ${ }^{1,2)}$ Program Studi Pendidikan LuarSekolah, STKIP Siliwangi
}

\begin{abstract}
ABSTRAK
Penelitian ini membahas tentang pemberdayaan para anggota Persatuan Isteri Prajurit (Persit) dalam meningkatkan kemandirian melalui Kegiatan Pos Pelayanan Terpadu di Brigade Infanteri 15 Kujang II Cimahi. Tujuannya untuk mendeskripsikan kegiatan Pos Pelayanan Terpadu di Brigade Infanteri 15 Kujang II Cimahi dan untuk mendeskripsikan manfaat dari pemberdayaan anggota Persatuan Isteri Prajurit (Persit) dalam melaksanakan kegiatan Pos Pelayanan Terpadu di Brigade Infanteri 15 Kujang II Cimahi. Penelitian ini adalah penelitian kualitatif. Instrumen dalam penelitian ini adalah yang melakukan penelitian itu sendiri, yaitu peneliti. Teknik pengumpulan data dilakukan dengan tiga cara yaitu observasi, wawancara dan dokumentasi. Kegiatan yang telah dilaksanakan oleh kader Poyandu Mawar Brigif 15 Kujang II Cimahi sesuai dengan kegiatan pokok menurut Departemen Kesehatan RI tahun 2006 diantaranya:kesehatan Ibu dan anak, imunisasi, pencegahan dan penanggulangan diare, gizi. Manfaat yang diperoleh kader posyandu dalam melaksanakan kegiatan di Posyandu Brigade Infanteri 15 Kujang II Cimahi yaitu kader posyandu merasa percaya diri dalam lingkungan sosialnya, kader mempunyai banyak teman (sosialisasinya baik), kader menjadi lebih mandiri dan disiplin, kader merasa terhormat bias bergabung sebagai kader Posyandu sehingga sosialisasi dengan warga Asrama lebih dekat, kader juga merasa bertambah pengetahuannya tentang kesehatan dasar bagi ibu dan anak.
\end{abstract}

Kata Kunci: Pemberdayaan, Persatuan Isteri Prajurit (Persit), Pos Pelayanan Terpadu.

\begin{abstract}
This study discusses the empowerment of the members of the Union of Soldiers Wife (Persit) in increasing the self-reliance through activities in the Integrated Service Post 15 Cleaver II Infantry Brigade Cimahi. The aim is to describe the activities in the Integrated Service Post 15 Cleaver II Infantry Brigade Cimahi and to describe the benefits of empowering members of the Union of Soldiers Wife (Persit) in carrying out activities in the Integrated Service Post 15 Cleaver II Infantry Brigade Cimahi. This study is a qualitative research. Instruments in this study is that doing research itself, which researchers. Data was collected in three ways: observation, interviews and documentation. Activities carried out by cadres Poyandu Rose Brigif 15 Cleaver II Cimahi according to the principal activity according to the Ministry of Health in 2006 include: mother and child health, immunization, prevention and control of diarrhea, malnutrition. The benefits cadre's in conducting at the Posyandu Infantry Brigade 15 Cleaver II Cimahi namely cadre's feeling confident in their social environment, the cadres have many friends (socialization good), cadres become more independent and disciplined, cadre honored bias join as Posyandu so that familiarization with hostel residents closer, cadres also feel increased knowledge about basic health for mother and child.
\end{abstract}

Keywords: Empowerment, Warrior Wives Association (Persit), Integrated Service Post.

\section{A. PENDAHULUAN}

Manusia adalah mahluk sosial. Dalam melaksanakan kegiatan sehari-hari, manusia tidak bisa hidup sendiri. Setiap manusia harus bermasyarakat. Setiap warga masyarakat ingin mempunyai kehidupan yang baik, ingin hidup maju, ingin hidup sejahtera dan juga ingin hidup bersatu dalam kedamaian. Masyarakat ingin perubahan ke arah yang lebih baik. 
Pengorganisasian merupakan jembatan untuk melakukan perubahan dalam masyarakat. Karena organisasi merupakan wadah untuk mencapai tujuan dan cita-cita masyarakat secara berkesinambungan. Pengorganisasian akan mendorong aksi bersama (collective action) untuk melakukan perubahan ke arah positif. Untuk itu, Persatuan Isteri Prajurit (Persit) Kartika Chandra Kirana merupakan organisasi Tentara Nasional Indonesia (TNI) Angkatan Darat yang turut serta mendukung anggotanya gar bisa berubah ke arah yang positif. Persatuan Isteri Prajurit mutlak tidak dapat dipisahkan dari Tentara Nasional Indonesia (TNI) Angkatan Darat, baik dalam melaksanakan tugas organisasi maupun dalam kehidupan pribadi.

Oleh karena itu, setiap isteri prajurit Tentara Nasional Indonesia (TNI) Angkatan Darat harus dapat membantu Tentara Nasional Indonesia Angkatan Darat dalam menyukseskan tugasnya baik sebagai kekuatan pertahanan maupun sebagai komponen pembangunan bangsa untuk mencapai cita-cita bangsa Indonesia. Kegiatan Persit antara lain melakukan kegiatan di bidang organisasi, ekonomi, pendidikan, budaya dan sosial dengan persetujuan pembina utama Persit Kartika Chandra Kirana atau Pembina dan sepengetahuan Dharma Pertiwi setingkat.

Dalam hal ini, organisasi Persatuan Isteri Prajurit (Persit) telah dan akan selalu melakukan pemberdayaan terhadap anggotanya agar anggota Persatuan Isteri Prajurit (Persit) dapat berubah ke arah yang positif yaitu menjadi pribadi yang aktif, kreatif dan mandiri.

Memposisikan isteri prajurit agar bisa efektif dalam berorganisasi memang perlu dicarikan berbagai alternatif strategi pemberdayaannya. Pilihan strategi yang tepat diharapkan dapat meningkatkan kemampuan dan kemandirian para istri prajurit. Pemberdayaan pada dasarnya adalah upaya menjadikan suasana kemanusiaan yang adil dan beradab menjadi semakin efektif secara struktural, baik dalam kehidupan keluarga, masyarakat, negara, regional, internasional, maupun dalam bidang politik, ekonomi dan lainlain. Dengan kata lain memberdayakan adalah memampukan dan memandirikan masyarakat.

Cook dan Macaulay (1997:1) memberikan definisi pemberdayaan sebagai alat penting untuk memperbaiki kinerja organisasi melalui penyebaran pembuatan keputusan dan tanggung jawab (Mulyana, 2008:49). Memberdayakan adalah memampukan dan memandirikan masyarakat. Kegiatan pemberdayaan masyarakat mencakup identifikasi kebutuhan dan permasalahan masyarakat, identifikasi sumber daya dan potensi masyarakat, dan merumuskan tindakan bersama berdasarkan potensi yang ada untuk meningkatkan taraf hidup. Dalam hal ini Persatuan isteri Prajurit di lingkungan Brigade Infanteri 15 Kujang II Cimahi memberdayakan anggotanya yang ada di lingkungan asrama Brigade Infanteri 15 Kujang II Cimahi untuk samasama melaksanakan program Pos Pelayanan Terpadu, yaitu Posyandu Mawar.

Pos Pelayanan Terpadu atau disingkat Posyandu merupakan pos pelayanan kesehatan bayi dan balita dimana pelayanan yang diberikan posyandu sangat dibutuhkan untuk memberikan kemudahan dan keuntungan bagi kesehatan masyarakat. Posyandu merupakan salah satu bentuk upaya kesehatan bersumber daya masyarakat (UKBM), yang merupakan wahana pemberdayaan masyarakat yang dibentuk atas dasar kebutuhan masyarakat, dikelola oleh, dari, untuk dan bersama masyarakat, dengan bimbingan dari petugas Puskesmas, lintas sektor dan lembaga terkait lainnya.

Sesuai dengan latar belakang tersebut, maka peneliti melakukan penelitian dengan judul "Pemberdayaan anggota Persatuan Isteri Prajurit (Persit) dalam meningkatkan Kemandirian melalui Kegiatan Pos pelayanan Terpadu (Posyandu) di Brigade Infanteri 15 Kujang II Cimahi”.

\section{B. KAJIAN TEORI DAN METODE}

\section{Kajian Teori}

\section{a. Pemberdayaan Masyarakat}

\section{1) Konsep Pemberdayaan Dalam Pendidikan Non Formal}

Pemberdayaan adalah upaya yang terencana dan sistematis yang dilakukan oleh, untuk dan terjadi di masyarakat untuk meningkatkan kualitas hidup dalam semua aspek kehidupan baik ekonomi, sosial dan budaya (Mulyana, 2005:6). Menurut Lahut dan Babari (1993), Pemberdayaan meliputi tiga hal yaitu:

a) Power to mengandung makna daya kekuatan untuk berbuat, berkarya dan berkreasi. Power to mencakup kemampuan berpikir, penguasaan 
IPTEK, penguasaan keterampilan, kemampuan memecahkan masalah, mengambil keputusan dan berkarya/produktif.

b) Power with merupakan kondisi atas kemampuan bekerja sama, kekuatan sama, dan kepedulian sosial.

c) Power within yaitu unsur pribadi yang terliput didalamnya kepercayaan diri, jati diri, komitmen dan kepribadian.

Pemberdayaan merupakan usaha yang menganut prinsip ekosistem yang penuh peduli terhadap ketersediaan, kemanfaatan, dan kesinambungan. Erat kaitannya dengan pembentukan perilaku masyarakat yang berwawasan masa depan. Pemberdayaan tidak hanya sekedar menghasilkan nilai tambah tetapi nilai manfaat yang berorientasi kebutuhan masyarakat. Pemberdayaan adalah upaya memampukan (enabling) masyarakat kecil atau bawahan yang selama ini dianggap tidak atau kurang berperan agar meningkat dan memiliki kemampuan yang lebih baik sehubungan dengan status dan peranan mereka di dalam sistem sosial (Mulyana, 2008:51).

Sistem sosial dapat berupa dunia usaha, organisasi, masyarakat maupun sistem sosial lainnya. Tatang M Amirin (1984) dalam Taneko (1986:1) menyatakan bahwa istilah sistem berasal dari bahasa Yunani "systema", yang mempunyai pengertian sebagai berikut:

(1) Suatu hubungan yang tersusun dari sekian banyak bagian.

(2) Hubungan yang berlangsung di antara satuansatuan atau komponen-komponen secara teratur.

Istilah pemberdayaan telah merambah pada segenap sisi kehidupan manusia. Kata pemberdayaan mula-mula dipakai dalam bidang pendidikan non formal oleh Kindervatter (1979). Dalam studinya terhadap pendidikan non formal di Indonesia dan Thailand 1976 untuk kepentingan studi doktornya, mengajukan suatu disertasi tentang peranan pendidikan non formal (nama lain dari PLS) merupakan suaru proses pemberdayaan (Kindervatter, 1979:vii). Salah satu contoh proses pemberdayaan yang dia berikan adalah peningkatan peran warga belajar untuk mengontrol pengambilan keputusan, sumber-sumber daya, dan institusi yang berpengaruh terhadap kehidupan mereka.

Simpulan dari studi tersebut adalah memberikan garis-garis besar bagi kreasi pendidikan non formal dalam mendukung proses pembangunan terbaru. Dan nampaknya saran tersebut diikuti oleh para advokator, pembela maupun pemimpin program pengembangan masyarakat saat ini, baik secara sengaja ataupun tidak disengaja (Mulyana, 2008:48). Konsep pemberdayaan merupakan upaya menjadikan suasana kemanusiaan yang adil dan beradab menjadi semakin efektif secara struktural, baik dalam kehidupan keluarga, masyarakat, negara, regional, internasional, maupun dalam bidang politik, ekonomi dan lain-lain.

\section{2) Unsur-Unsur Pemberdayaan}

Pemberdayaan telah menjadi upaya yang harus dikembangkan, dikarenakan saat ini banyak sekali permasalahan masyarakat yang karena keterbatasan akses pemerintah kepada masyarakat. Program-program pembangunan sulit mencapai sasaran yang maksimal. Keterbatasan pemerintah untuk dapat memenuhi tuntutan-tuntutan masyarakat yang erat hubungannya dengan keterbatasan pemerintah dalam hal anggaran, maka pemberdayaan masyarakat merupakan salah satu jalan yang paling memungkinkan.

Keberhasilan dalam proses pemberdayaan akhirnya dapat menumbuhkan timbulnya percaya diri dan selanjutnya masyarakat bisa mengembangkannya ke arah yang lebih baik. Dan masyarakat tersebut menjadi masyarakat yang berdaya.

Menurut Suhendra (2006:86) dalam Sobahi dan Suhana (2011: 103) menyebutkan indikator masyarakat yang berdaya adalah:

1) Mempunyai kemampuan menyiapkan dan menggunakan pranata dan sumber-sumber yang ada di masyarakat.

2) Dapat berjalannya bottom up planning

3) Kemampuan dan aktivitas ekonomi

4) Kemampuan menyiapkan hari depan keluarga

5) Kemampuan menyampaikan pendapat dan aspirasi tanpa adanya tekanan.

6) Masyarakat yang berdaya akan mampu dan kuat untuk dapat berpartisipasi dalam pembangunan, mampu mengawasi jalannya pembangunan dan juga menikmati hasil pembangunan.

\section{3) Proses Pemberdayaan}

Proses pemberdayaan masyarakat untuk melahirkan masyarakat yang memiliki sifat ataupun ciri-ciri masyarakat berdaya seperti yang diharapkan harus dilakukan secara berkesinambungan. Slamet (2003) menjelaskan 
lebih rinci bahwa yang dimaksud dengan masyarakat berdaya adalah masyarakat yang tahu, mengerti, faham, termotivasi, berkesempatan, memanfaatkan peluang, berenergi, mampu bekerjasama, tahu berbagai alternative, mampu mengambil keputusan, berani mengambil resiko, mampu mencari dan menangkap informasi dan mampu bertindak sesuai dengan situasi (Sobahi dan Suhana, 2011: 105).

Pranaka \& Vidhyandika (1996) menjelaskan bahwa "proses pemberdayaan mengandung dua kecenderungan. Pertama, pemberdayaan yang menekankan pada proses memberikan atau mengalihkan sebagian kekuatan, kekuasaan atau kemampuan kepada masyarakat agar individu lebih berdaya. Kecenderungan tersebut dapat disebut sebagai kecenderungan primer dari makna pemberdayaan. Kedua atau kecenderungan sekunder menekankan pada proses menstimulasi, mendorong atau memotivasi individu agar mempunyai kemampuan atau keberdayaan untuk menentukan apa yang menjadi pilihan hidupnya melalui proses dialog".

\section{4) Pemberdayaan untuk Memandirikan Masyarakat}

Setiap komponen masyarakat selalu memiliki kemampuan atau yang disebut potensi. Keutuhan potensi ini akan dapat dilihat apabila diantara mereka mengintegrasikan diri dan bekerja sama untuk dapat berdaya dan mandiri. Terkait dengan tujuan pemberdayaan, Sulistiyani (2004) menjelaskan bahwa tujuan yang ingin dicapai dari pemberdayaan masyarakat adalah untuk membentuk individu dan masyarakat menjadi mandiri. Kemandirian tersebut meliputi kemandirian berpikir, bertindak dan mengendalikan apa saja yang mereka lakukan (Sobahi dan Suhana, 2011:107).

Pemberdayaan masyarakat merupakan suatu upaya untuk meningkatkan harkat dan martabat lapisan masyarakat yang dalam kondisi sekarang tidak mampu untuk melepaskan diri dari perangkap kemiskinan dan keterbelakangan. Dengan kata lain memberdayakan adalah memampukan dan memandirikan masyarakat. Adapun pemberdayaan masyarakat senantiasa menyangkut dua kelompok yang saling terkait, yaitu masyarakat sebagai pihak yang diberdayakan dan pihak yang menaruh kepedulian sebagai pihak yang memberdayakan.
Keberdayaan dalam konteks masyarakat adalah kemampuan individu yang bersenyawa dalam masyarakat dan membangun keberdayaan masyarakat yang bersangkutan. Suatu masyarakat yang sebagian besar anggotanya sehat fisik dan mental, terdidik dan kuat, tentunya memiliki keberdayaan yang tinggi. Pemberdayaan masyarakat merupakan unsur dasar yang memungkinkan suatu masyarakat bertahan, dan dalam pengertian yang dinamis mengembangkan diri dan mencapai kemajuan.

\section{b. Persatuan Istri Prajurit}

\section{1) Pengertian Persatuan Istri Prajurit}

Persatuanistriprajurit yang selanjutnya disingkat Persit Kartika Chandra Kirana adalah kelanjutan danpenyempurnaandariorganisasi yang terdahulu, yaitu Persatuan Istri Tentara yang didirikan oleh Ny. Ratu Aminah pendiri Persit pada tanggal 3 april 1946 di Purwakarta, Jawa Barat. Dimana organisasi ini didirikan berasaskan Pancasila dan Undang-Undang Dasar 1945. Didasari rasa persatuan, kesatuan, persaudaraan, dan kekeluargaan serta rasa senasib sepenanggungan dan seperjuangan sebagai istri prajurit (http://korem033wp.mil.id/serba-serbi/).

Sebagai istri prajurit TNI Angkatan Darat tidak dapat dipisahkan dari TNI Angkatan Darat, baik dalam melaksanakan tugas organisasi maupun dalam kehidupan pribadi. Oleh karena itu istri prajurit TNI Angkatan Darat harus membantu TNI Angkatan Darat dalam mensukseskan tugasnya baik sebagai kekuatan pertahanan keamanan maupun sebagai komponen pembangunan bangsa.

Sejalan dengan perkembangan selanjutnya Persit Kartika Chandra Kirana menyesuaikan organisasinya dengan reorganisasi TNI Angkatan Darat yang dimulai tahun 1984 dengan demikian kedudukan Persit Kartika Chandra Kirana merupakan organisasi kemasyarakatan yang berinduk pada organisasi kemasyarakatan Dharma pertiwi.

\section{2) Tugas Pokok dan Tujuan Persatuan Istri Prajurit}

Persit Kartika Chandra Kirana berbentuk badan perjuangan yang merupakan organisasi kemasyarakatan yang berinduk pada organisasi kemasyarakatan Dharma Pertiwi. Persit Kartika Chandra Kirana adalah suatu badan pelaksanaan 
yang berdiri sendiri, berkedudukan langsung di bawah Kepala Staf TNI Angkatan Darat yang sifat kegiatannya diatur secara ekstra struktural di dalam struktur organisasi TNI Angkatan Darat.

Kegiatan Persatuan Istri Prajurit (PERSIT) Kartika Chandra Kirana adalah untuk mendukung suami dalam melaksanakan tugasnya dan hal ini tercantum dalam tugas pokok yaitu:

a) Membantu Kepala Staf Angkatan Darat dalam pembinaan isteri prajurit dan keluarganya khususnya bidang mental, fisik, kesejahteraan dan moril sehingga dapat berpengaruh terhadap keberhasilan tugas prajurit.

b) Mendukung kebijaksanaan pemimpin TNI dengan membina dan mengarahkan perjuangan isteri anggota TNI Angkatan Darat, menciptakan rasa persaudaraan dan kekeluargaan, rasa persatuan dan kesatuan serta kesadaran nasional.

Adapun tujuan Persatuan Isteri Prajurit (PERSIT) Kartika Chandra Kirana sebagai berikut:

(1) Ikut serta mewujudkan masyarakat Indonesia yang adil dan makmur material maupun spiritual berasaskan Pancasila.

(2) Membantu tugas pembinaan Tentara Nasional Indonesia (TNI) sebagai kekuatan pertahanan keamanan maupun sebagai komponen pembangunan bangsa.

(3) Mewujudkan kesatuan perjuangan istri anggota Tentara Nasional Indonesia (TNI) yang berdasarkan rasa senasib, sepenanggungan dan seperjuangan (http://serbapersit.blogspot.co.id/2012).

\section{3) Keanggotaan Persatuan Istri Prajurit}

a) Isteri prajurit organik Tentara Nasional Indonesia Angkatan Darat yang:
a) Suaminya masih dinas aktif di dalam organisasi TNI Angkatan Darat
b) Suaminya ditugaskan di Iuar lingkungan TNI Angkatan Darat tetapi masih dinas aktif.
c) Suaminya memasuki masa persiapan pensiun dan diangkat sebagai anggota cadangan dalam dinas aktif (DDA).

b) Isteri purnawirawan TNI Angkatan Darat sebagai anggota yang ditugasi atas nama persatuan isteri prajurit (Persit) Kartika Chandra Kirana dengan persetujuan Pembina Utama Persit Kartika Chandra Kirana atau pembina.

\section{c. Pos Pelayanan Terpadu}

\section{1) Pengertian Pos Pelayanan Terpadu (Posyandu).}

Posyandu merupakan salah satu bentuk Upaya kesehatan bersumber Daya Manusia (UKBM) yang dikelola dan diselenggarakan dari, oleh, untuk dan bersama masyarakat dalam penyelenggaraan pembangunan kesehatan, guna memberdayakan masyarakat dan memberikan kemudahan kepada masyarakat dalam memperoleh pelayanan kesehatan dasar untuk mempercepat penurunan angka kematian ibu dan bayi (Departemen Kesehatan RI, 2006:11).

Posyandu adalah suatu wadah komunikasi teknologi dalam bidang kesehatan masyarakat dari keluarga berencana dari masyarakat, oleh masyarakat dan untuk masyarakat dengan dukungan pelayanan serta pembinaan teknis dari petugas kesehatan dan keluarga berencana yang mempunyai nilai strategis untuk pengembangan sumber daya manusia sejak dini (Sembiring, 2004). Posyandu merupakan garda depan kesehatan balita dimana pelayanan yang diberikan posyandu sangat dibutuhkan untuk memberikan kemudahan dan keuntungan bagi kesehatan masyarakat, khususnya bayi dan balita. Kegiatan Posyandu terdiri dari Kesehatan Ibu dan Anak.

\section{2) Tujuan Pos Pelayanan Terpadu}

Menurut Departemen Kesehatan RI (2006:12) ada tujuan umum dan tujuan khusus atas diselenggarakannya posyandu sebagai berikut:

a) Tujuan Umum

Menunjang percepatan penurunan Angka Kematian Ibu (AKI) dan Angka Kematian Bayi (AKB )di Indonesia melalui upaya pemberdayaan masyarakat.

b) Tujuan khusus

1) Meningkatnya peran masyarakat dalam penyelenggaraan upaya kesehatan dasar, terutama yang berkaitan tentang penurunan Angka Kematian Ibu (AKI) dan Angka Kematian Bayi (AKB ).

2) Meningkatnya peran lintas sektor dalam penyelenggaraan posyandu, terutama berkaitan dengan penurunan Angka Kematian Ibu (AKI) dan Angka Kematian Bayi (AKB ).

3) Meningkatnya cakupan dan jangkauan pelayanan kesehatan dasar, terutama yang berkaitan dengan penurunan Angka 
Kematian Ibu (AKI) dan Angka Kematian Bayi (AKB).

\section{3) Sasaran Posyandu}

Sasaran posyandu adalah seluruh masyarakat diantaranya menurut Departemen Kesehatan RI (2006:13) sebagai berikut:

a) Bayi

b) Anak balita

c) Ibu hamil, ibu melahirkan, ibu nifas dan ibu menyusui

d) Pasangan Usia Subur (PUS).

\section{4) Fungsi Pos Pelayanan Terpadu}

Menurut Departemen Kesehatan RI (2006:13) sebagai berikut:

a) Sebagai wadah pemberdayaan masyarakat dalam alih informasi dan ketrampilan dari petugas kepada masyarakat dan antar sesama masyarakat dalam rangka mempercepat penurunan Angka Kematian Ibu (AKI) dan Angka Kematian Bayi (AKB ).

b) Sebagai wadah untuk mendekatkan pelayanan kesehatan dasar, terutama berkaitan dengan penurunan Angka Kematian Ibu (AKI) dan Angka Kematian Bayi (AKB ).

\section{5) Manfaat Pos Pelayanan Terpadu}

Manfaat posyandu menurut Departemen Kesehatan RI (2006:14) adalah:

a) BagiMasyarakat

(1) Memperoleh kemudahan untuk mendapatkan informasi dan pelayanan kesehatan dasar, terutama berkaitan dengan penurunan Angka Kematian Ibu (AKI) dan Angka Kematian Bayi (AKB ).

(2) Memperoleh bantuan secara profesional dalam pemecahan masalah kesehatan terutama terkait Kesehatan Ibu dan Anak (KIA).

(3) Efisiensi dalam mendapatkan pelayanan terpadu kesehatan dan sektor lain terkait.

b) Bagi kader, pengurus posyandu dan tokoh masyarakat

(1) Mendapatkan informasi terdahulu tentang upaya kesehatan yang terkait dengan penurunan Angka Kematian Ibu (AKI) dan Angka Kematian Bayi (AKB ).

(2) Dapat mewujudkan aktualisasi dirinya dalam membantu masyarakat menyelesaikan masalah kesehatan terkait dengan penurunan Angka Kematian Ibu (AKI) dan Angka Kematian Bayi (AKB )

c) Bagi Puskesmas

(1) Optimalisasi fungsi puskesmas sebagai pusat penggerak pembangunan berwawasan kesehatan, pusat pemberdayaan masyarakat, pusat pelayanan kesehatan strata pertama.

(2) Dalam lebih spesifik membantu masyarakat dalam pemecahan masalah kesehatan sesuai kondisi setempat.

(3) Meningkatkan efisiensi waktu, tenaga dan dana melalui pemberian pelayanan secara terpadu.

d) Bagi sektor lain

(1) Dapat lebih spesifik membantu masyarakat dalam pemecahan, masalah sektor terkait, utamanya yang terkait dengan upaya penurunan Angka Kematian Ibu (AKI) dan Angka Kematian Bayi (AKB ) sesuai kondisi setempat.

(2) Meningkatkan efisiensi melalui pemberian pelayanan secara terpadu sesuai dengan tugas pokok dan fungsi masing-masing sektor.

\section{6) Kegiatan Posyandu}

Kegiatan utama posyandu menurut Departemen Kesehatan RI (2006:26) adalah sebagai berikut:

1) Kesehatan Ibu dan Anak (Ibu hamil, Ibu nifas dan menyusui, bayi dan balita). Kegiatannya mencakup: penimbangan berat badan, penyuluhan, senam ibu hamil, deteksi dini tumbuh kembang anak.

2) Keluarga Berencana.Pelayanan KB mencakup pemberian kondom, pemberian pil ulangan, suntikan $\mathrm{KB}$, konseling $\mathrm{KB}$.

3) ImunisasiPelayanan imunisasi di posyandu hanya dilaksanakan apabila ada petugas Puskesmas.

4) Gizi. Pelayanan gizi di Posyandu dilakukan oleh kader posyandu.

5) Pencegahan dan Penanggulangan Diare.Pencegahan diare di Posyandu diantaranya dengan penyuluhan perilaku hidup bersih dan sehat.

\section{Metode}

Pada penelitian ini peneliti menggunakan pendekatan kualitatif. Penelitian kualitatif adalah penelitian yang menghasilkan penemuanpenemuan yang tidak dapat dicapai dengan menggunakan prosedur statistik atau dengan cara- 
cara kuantifikasi. Boghdan and taylor (1992) menjelaskan bahwa penelitian kualitatif menghasilkan data deskriptif berupa ucapan, tulisan dan perilaku orang-orang yang diamati (Ghony dan Almanshur, 2012:13).

Instrumen dalam penelitian kualitatif adalah yang melakukan penelitian itu sendiri, yaitu peneliti (Ghony dan Almanshur, 2012:95). Peneliti dalam penelitian kualitatif merupakan orang yang membuka kunci, menelaah, dan mengeksplorasi seluruh ruang secara cermat, tertib dan leluasa, bahkan ada yang menyebutnya sebagai key instrument.

Teknik pengumpulan data merupakan langkah yang paling strategis dalam penelitian, karena tujuan utama dari penelitian adalah mendapatkan data (Sugiyono, 2013:224). Maka teknik pengumpulan data dapat dilakukan dengan observasi, wawancara dan dokumentasi.

a. Observasi. Nasution (1998) menyatakan bahwa, observasi adalah dasar semua ilmu pengetahuan. Dalam penelitian ini menggunakan observasi terus terang atau tersamar, yakni peneliti dalam melakukan pengumpulan data menyatakan terus terang kepada sumber data, bahwa ia sedang melakukan penelitian. (Sugiyono, 2013:228). Pada penelitian ini, peneliti melakukan obseravasi pada kegiatan posyandu selama dua kali yaitu pada minggu kedua bulan Agustus dan minggu kedua bulan September 2015.

b. Wawancara. Esterberg (2002) mendifinisikan wawancara adalah merupakan pertemuan dua orang untuk bertukar informasi dan ide melalui tanya jawab, sehingga dapat dikonstruksikan makna dalam suatu topik tertentu. (Sugiyono, 2013:231). Peneliti menggunakan wawancara semiterstruktur, dimana peneliti bisa menemukan permasalahan dengan lebih terbuka, pihak yang diajak wawancara diminta pendapat dan ide-idenya.

c. Dokumentasi. Dokumen merupakan catatan peristiwa yang sudah berlalu (Sugiyono, 2013:240). Dalam penelitian ini dokumentasi berbentuk tulisan dan gambar.

Adapun rincian pelaksanaan penelitian sebagai berikut:

1) Pada tanggal 28 Juli 2015, peneliti memberikan pengantar tentang tujuan penelitian dan membuat kesepakatan dengan subjek penelitian mengenai waktu dan tempat untuk melakukan wawancara berdasarkan pedoman wawancara yang dibuat.

2) Setelah itu pada tanggal 11 Agustus 2015, peneliti melakukan observasi dan wawancara, kemudian peneliti memindahkan hasil observasi dalam bentuk tulisan. Selanjutnya, peneliti merangkum isi dari observasi dan wawancara kemudian menggaris besarkan apa yang menjadi catatan mengenai penelitian ini.

3) Setelah itu, pada tanggal 8 September 2015 , peneliti melakukan observasi lagi secara berkelanjutan dan mendalam untuk melihat realitas kegiatan anggota PERSIT dalam hal meningkatkan kemandirian melalui program POSYANDU. Hasil observasi, peneliti tuangkan dalam bentuk teks naratif.

4) Selanjutnya, peneliti melakukan mengumpulkan hasil observasi dua bulan lalu untuk dapat menyimpulkan hasil dari penelitian yang telah dilakukan.

Dalam penelitian kualitatif, teknik analisis data yang digunakan sudah jelas, yaitu diarahkan untuk menjawab rumusan masalah atau menguji hipotesis yang telah dirumuskan dalam proposal (Sugiyono, 2013:243). Komponen dalam analisis data sebagai berikut:

a) Reduksi Data

Data yang diperoleh dilapangan cukup banyak, peneliti melakukan dua kali observasi dalam penelitian ini. Oleh karena itu, dalam observasi penelitian ini perlu dicatat secara rinci dan teliti. Peneliti merangkum, memilih hal-hal yang pokok dicari tema dan polanya. Dengan demikian akan memberikan gambaran yang lebih jelas dan mempermudah peneliti dalam pengumpulan data.

b) Penyajian Data

Dalam penyajian data, setelah melakukan observasi lalu peneliti melakukan pencatatan dalam bentuk uraian singkat. Dengan menyajikan data maka akan mempermudah untuk memahami apa yang terjadi.

c) Verfikasi

Penarikan kesimpulan atau verifikasi merupakan teknik akhir dalam analisis data. Kesimpulan yang berupa deskripsi yang jelas.

\section{Hasil dan Pembahasan.}

\section{Hasil}

Dalam melaksanakan penelitian, peneliti kemudian melakukan observasi untuk mencari 
informasi dan melengkapi data yang telah dipersiapkan sebelumnya. Dalam mendapatkan informasi, peneliti mengajukan pertanyaan melalui observasi maupun wawancara. Deskripsi data pada penelitian ini menjelaskan tentang kegiatan yang dilaksanakan oleh para kader posyandu oleh para istri prajurit. Berikut deskripsi hasil penelitian yang telah dilaksanakan oleh peneliti di posyandu Mawar Brigif 15 Kujang II Cimahi. Hasil observasi pada tanggal 11 Agustus 2015 dan 08 September 2015 sebagai berikut:

Langkah-langkah Pelaksanaan Kegiatan

a. Penimbangan Bayi dan Balita:

1) Persiapan (Persiapan dilaksanakan sehari sebelum kegiatan posyandu dilaksanakan).

2) Kader merencanakan kegiatan di gedung Posyandu Mawar.

3) Kegiatan direncanakan bersama ketua posyandu Mawar dan para kader.

b. Perencanaan kegiatan meliputi:

1) Pembentukan tenaga pelaksanaan dan tugasnya.

2) Penyusunan jadwal kegiatan.

3) Penentuantempatkegiatan.

4) Cakupankeluarga/sasaran.

5) Perlengkapan yang diperlukan.

Sehari sebelum pelaksanaan kegiatan penimbangan bayi/balita para kader melaksanakan tugasnya sebagai berikut:

a) Sebelum pelaksanaan para kader memberi pengumuman melalui pengeras suara di mesjid Nurul Kujang, yang ditujukan kepada ibu-ibu yang mempunyai bayi dan anak balita agar datang ke posyandu.

b) Kader menyediakan alat-alat yang diperlukan, meja, kursi, buku register, poster, KMS, oralit, vit. A.

(1) Pelaksanaan kegiatan bayi/balita.

penimbangan

Padaharipelaksanaan, peneliti mengamati kegiatan para kader dalam melaksanakan kegiatan posyandu. Sebelum memulai kegiatan posyandu yaitu acara penimbangan balita, para kader mempersiapkan dan membersihkan tempat terlebih dahulu. Setiap kader dibagi tugas dalam mempersiapkan tempat. Dalam pengaturan meja terbagi atas beberapa meja sebagai berikut:

Meja I : Pendaftaran.

Meja II : Penimbanganbayidanbalita.

Meja III: Pengisian Kartu Menuju Sehat.
Meja IV: Pelayananoralit, vitamin A dosistinggi. Meja V: Pelayanan makanan untuk bayi dan balita

Meja I berperan sebagai tempat pendaftaran bagi warga asrama Brigif yang akan melakukan penimbangan balita. Meja II berperan sebagai tempat untuk menimbang berat dan mengukur tinggi bayi dan balita. Meja III berperan sebagai tempat pengisian Kartu Menuju Sehat. Meja IV berperan sebagai tempat pelayanan imunisasi dan pengobatan sederhana. Khusus bulan Agustus, para bayi dan balita diberikan vitamin A. Meja V berperan sebagai tempat pelayanan pemberian makanan sehat oleh para kader posyandu.

Awal pelayanan kesehatan kepada warga asrama Brigif 15 Kujang II dimulai dengan para kader melaksanakan tugasnya sesuai dengan mejanya masing-masing. Pada meja pertama yaitu kader mencatat pendaftaran. Dalam mencatat pendaftaran kader menuliskan nama bayi/balita tersebut, lalu usia bayi/balita tersebut lalu menulis nama ayah dan pangkat ayah dari bayi/balita tersebut. Kemudian beranjak pada meja kedua. Pada meja kedua kader menimbang berat dan mengukur tinggi bayi dan balita.

Penimbangan bayi, balitadicatat di KMS. Di bawahgarismerah, $3 \mathrm{x}$ tidak naik, sakit dirujuk kepetuga skesehatan; usia 3-14 bulan pelayanan imunisasi; dan diare diberi oralit, dan penyuluhan kepada orangtua. Dan para ibu yang mengantar anaknya harus mengingat berat dan tinggi anak mereka lalu melanjutkan ke meja ketiga.

Pada meja ketiga yaitu kader menuliskan berat dan tinggi bayi/balita di buku yang telah disediakan. Setelah itu beranjak ke meja empat yaitu meja untuk imunisasi. Berhubung observasi pertama yaitu di bulan Agustus, pada bulan ini dibagikan Vitamin A kepada bayi/balita secara gratis. Para petugas sendiri yang memberikan vitamin A tersebut kepada bayi/balita. Dan meja terakhir yaitu meja kelima. Dimana pada meja ini para kader memberikan makanan sehat kepada bayi/balita yang telah mengikuti acara penimbangan bayi dan balita.

Hasil observasi dan wawancara yang peneliti lakukan mengenai pemberdayaan anggota Persatuan Isteri Prajurit (Persit) dalam meningkatkan kemandirian melalui Kegiatan Pos Pelayanan Terpadu (Posyandu) di Brigade Infanteri 15 Kujang II Cimahi yaitu: 
Pertama, peneliti mewawancara kader 1 yang menguraikan beberapa kegiatan-kegiatan yang dilakukan oleh para kader dalam pelaksanaan posyandu adalah sebagai berikut:

a. Setiap bulan pada minggu kedua, kader posyandu menyelenggarakan penimbangan bayi dan balita. Bertempat di gedung posyandu Mawar Brigif 15 kujang II Cimahi

b. Pada akhir bulan di setiap bulannya, kader yang ditunjuk sebanyak 3 orang melaksanakan Loka Karya Mini (LOKMIN) di Puskesmas kelurahan Cimahi Tengah.

c. Setiap bulan Februari dan bulan Agustus, kader memberikan Vitamin A kepada bayi dan balita. Vitamin A tersebut didapatkan kader dari puskesmas secara gratis.

d. Seminggu sekali setiap hari jumat, kader melaksanakan kegiatan Jentik ke rumahrumah sekitar lingkungan asrama Brigif 15 Kujang II Cimahi.

e. Setahun sekali melaksanakan Pendataan Perilaku Hidup Bersih Sehat (PHBS).

f. Sebulan sekali para kader mendata ibu-ibu hamil di sekitar lingkungan asrama Brigif 15 Kujang II Cimahi.

g. Sebulan sekali para kader membuat laporan ibu melahirkan yang diserahkan langsung ke pihak puskesmas Cimahi Tengah.

h. Sebulan sekali para kader membuat laporan imunisasi ke puskesmas Cimahi Tengah.

Dalam hal membuat perencanaan kegiatan posyandu yaitu ketua posyandu mawar dan kader posyandu. Untuk penetapan jadwal dan pelaksanaan kegiatan posyandu yang dilaksanakan dalam sebulan semua kader berperan serta atau ikut andil dalam pelaksanaannya. Kegiatan yang telah dilaksanakan oleh para kader yaitu setiap bulan pada minggu kedua, kader posyandu menyelenggarakan penimbangan bayi dan balita. Bertempat di gedung posyandu Mawar Brigif 15 kujang II Cimahi Pada akhir bulan di setiap bulannya, kader yang ditunjuk sebanyak 3 orang melaksanakan Loka Karya Mini (LOKMIN) di Puskesmas kelurahan Cimahi Tengah, Setiap bulan Februari dan bulan Agustus, kader memberikan Vitamin A kepada bayi dan balita.

Kader 1 merasa puas atas kegiatan posyandu yang telah dilaksanakan di karenakan selain kader diberdayakan oleh kesatuan, kader juga di beri pelatihan mengenai kesehatan ibu dan anak. Tidak ada kendala dalam pelaksanaan kegiatan posyandu, karena segala sesuatu dipantau dan dibimbing atas izin dari ketua posyandu.
Pencapaian yang ingin dicapai yaitu kader 1 berharap lebih banyak lagi kegiatan posyandu yang bisa dilaksanakan seperti ibu hamil dan menyusui. Dan kader 1 pun berharap dukungan dari warga asrama agar semua kegiatan posyandu bisa dilaksanakan. Adapun manfaat setelah kader diberdayakan oleh organisasi persit yaitu kader merasa percaya diri, senang dan merasa bersyukur telah diberi amanat oleh ketua persit Brigif 15 Kujang II. Dan kader 1 juga merasakan lebih mandiri dan disiplin setelah diberdayakan melalui kegiatan Posyandu.

Kedua, peneliti mewawancara kader 2 yang juga menyebutkan beberapa kegiatan-kegiatan yang dilakukan oleh para kader dalam pelaksanaan posyandu yaitu setiap bulan menyelenggarakan penimbangan bayi dan balita, sebulan sekali para kader membuat laporan imunisasi ke puskesmas Cimahi Tengah, dan pada akhir bulan di setiap bulannya, kader yang ditunjuk sebanyak 3 orang melaksanakan Loka Karya Mini (LOKMIN) di Puskesmas kelurahan Cimahi Tengah, setiap bulan Februari dan bulan Agustus, kader memberikan Vitamin A kepada bayi dan balita, sebulan sekali para kader mendata ibu-ibu hamil di sekitar lingkungan asrama Brigif 15 Kujang II Cimahi, sebulan sekali para kader membuat laporan ibu melahirkan yang diserahkan langsung ke pihak puskesmas Cimahi Tengah.

Ketua posyandu dan kader yang membuat perencanaan kegiatan dan kaderlah yang menetapkan jadwal pelaksanaan kegiatan posyandu yang dilaksanakan dalam sebulan. Kegiatan yang telah dilaksanakan oleh para kader yaitu setiap bulan pada minggu kedua, kader posyandu menyelenggarakan penimbangan bayi dan balita. Pada akhir bulan di setiap bulannya, kader yang ditunjuk sebanyak 3 orang melaksanakan Loka Karya Mini (LOKMIN) di Puskesmas kelurahan Cimahi Tengah, Setiap bulan Februari dan bulan Agustus, kader memberikan Vitamin A kepada bayi dan balita.

Sebulan sekali para kader membuat laporan imunisasi ke puskesmas Cimahi Tengah. Kader 2 merasa puas atas kegiatan posyandu yang telah dilaksanakan, karena kader merasa diangkat derajatnya sehingga kader dapat berperan aktif dalam program organisasi juga. Dan kader 2 pun merasa sangat senang karena dengan menjadi kader posyandu, kader 2 jadi mempunyai banyak teman. Kader 2 merasa tidak menghadapi kendala dalam pelaksanaan kegiatan posyandu, karena 
ketua posyandu berperan serta dalam kegiatan posyandu.

Ada satu pencapaian yang ingin dicapai oleh kader 2 berharap mendapatkan dukungan dari warga asrama untuk kegiatan ibu hamil dan pasangan usia subur agar semua kegiatan posyandu bisa dilaksanakan. Manfaat yang dirasakan oleh kader 2 yaitu kader merasa terhormat bisa bergabung di kader Posyandu sehingga sosialisasi dengan warga asrama lebih dekat, dan kader juga merasa bertambah pengetahuannya tentang kesehatan dasar bagi ibu dan anak.

\section{Pembahasan}

Kegiatan apa saja yang dilaksanakan oleh para kader di Posyandu Brigade Infanteri 15 Kujang II Cimahi?

Menurut Departemen Kesehatan RI (2006:26) ada beberapa kegiatan utama di Posyandu adalah sebagai berikut:

a. Kesehatan Ibu dan Anak (Ibu hamil, Ibu nifas dan menyusui, bayi dan balita). Kegiatannya mencakup: penimbangan berat badan, penyuluhan, senam ibu hamil, deteksi dini tumbuh kembang anak.

b. Keluarga Berencana. Pelayanan KB mencakup pemberian kondom, pemberian pil ulangan, suntikan $\mathrm{KB}$, konseling $\mathrm{KB}$.

c. Imunisasi. Pelayanan imunisasi di posyandu hanya dilaksanakan apabila ada petugas Puskesmas.

d. Gizi. Pelayanan gizi di Posyandu dilakukan oleh kader posyandu.

e. Pencegahan dan Penanggulangan Diare. Pencegahan diare di Posyandu diantaranya dengan penyuluhan perilaku hidup bersih dan sehat.

Adapun beberapa kegiatan-kegiatan yang dilakukan oleh para kader dalam pelaksanaan posyandu adalah sebagai berikut: setiap bulan pada minggu kedua, kader posyandu menyelenggarakan penimbangan bayi dan balita, pada akhir bulan di setiap bulannya, kader yang ditunjuk sebanyak 3 orang melaksanakan Loka Karya Mini (LOKMIN) di Puskesmas kelurahan Cimahi Tengah, setiap bulan Februari dan bulan Agustus, kader memberikan Vitamin A kepada bayi dan balita, seminggu sekali setiap hari jumat, kader melaksanakan kegiatan Jentik ke rumahrumah sekitar lingkungan asrama Brigif 15 Kujang II Cimahi, setahun sekali melaksanakan pendataan
Perilaku Hidup Bersih Sehat (PHBS), sebulan sekali para kader mendata ibu-ibu hamil di sekitar lingkungan asrama Brigif 15 Kujang II Cimahi, sebulan sekali para kader membuat laporan ibu melahirkan yang diserahkan langsung ke pihak puskesmas Cimahi Tengah, sebulan sekali para kader membuat laporan imunisasi ke puskesmas Cimahi Tengah.

Untuk itu kegiatan posyandu yang sudah dilaksanakan oleh Posyandu Mawar sesuai dengan kegiatan pokok menurut Departemen Kesehatan RI, 2006 diantaranya:

1) Kesehatan Ibu dan Anak yang hanya mencakup kesehatan anak yaitu penimbangan balita.

2) Imunisasi. Pelayanan imunisasi di posyandu Mawar mendapatkan pendampingan dari petugas Puskesmas.

3) Pencegahan dan Penanggulangan Diare. Kader Posyandu mawar memberikan penyuluhan perilaku hidup bersih dan sehat.

4) Gizi. Kader Posyandu Mawar memberikan makanan sehat untuk bayi dan balita setiap kegiatan penimbangan bayi/balita.

Kegiatan utama Posyandu yang belum dilaksnakan oleh Posyandu Mawar yaitu:

a) Keluarga Berencana.

b) Kesehatan Ibu dan Anak (Ibu hamil, Ibu nifas dan menyusui)

Kedua kegiatan tersebut belum bisa dilaksanakan dikarenakan menurut hasil wawancara peneliti dengan kader 1 dan kader 2, kegiatan tersebut belum bisa dilaksnakan dikarenakan banyak warga asrama Brigif yang melakukan pelayanan $\mathrm{KB}$ dan periksa kehamilan diluar Posyandu dan belum adanya dukungan dan kepercayaan dari warga asrama Brigif 15.

Manfaat apa saja yang diperoleh dalam melaksanakan kegiatan Posyandu bagi para kader di Posyandu Brigade Infanteri 15 Kujang II Cimahi?

Menurut Mulyana (2008:51) menyebutkan bahwasannya pemberdayaan adalah upaya memampukan (enabling) masyarakat kecil atau bawahan yang selama ini dianggap tidak atau kurang berperan agar meningkat dan memiliki kemampuan yang lebih baik sehubungan dengan status dan peranan mereka di dalam sistem sosial. Pemberdayaan tidak hanya sekedar menghasilkan nilai tambah tetapi nilai manfaat yang berorientasi 
kebutuhan masyarakat. Konsep pemberdayaan merupakan upaya menjadikan suasana kemanusiaan yang adil dan beradab menjadi semakin efektif secara struktural, baik dalam kehidupan keluarga, masyarakat, negara, regional, internasional, maupun dalam bidang politik, ekonomi, dan lain-lain.Keberhasilan dalam proses pemberdayaan akhirnya dapat menumbuhkan timbulnya percaya diri dan selanjutnya masyarakat bisa mengembangkannya kearah yang lebih baik.

Hasil dari observasi dan wawancara peneliti dengan kader Posyandu sebagai berikut:

(1) Kader yang telah diberdayakan melalui kegiatan posyandu merasa percaya diri dalam lingkungan sosialnya.

(2) Kader mempunyai banyak teman (sosialisasinya baik).

(3) Kader menjadi lebih mandiri dan disiplin

(4) Kader merasa terhormat bisa bergabung di kader Posyandu sehingga sosialisasi dengan warga asrama lebih dekat.

(5) Kader juga merasa bertambah pengetahuannya tentang kesehatan dasar bagi ibu dan anak.

\section{KESIMPULAN}

Kegiatan yang telah dilaksanakan oleh kader Poyandu di Posyandu Mawar Brigif 15 Kujang II Cimahi sesuai dengan kegiatan pokok menurut Departemen Kesehatan RI tahun 2006 diantaranya:

1. Kesehatan Ibu dan Anak yang hanya mencakup kesehatan anak yaitu penimbangan balita.

2. Imunisasi. Pelayanan imunisasi di posyandu Mawar mendapatkan pendampingan dari petugas Puskesmas.

3. Pencegahan dan Penanggulangan Diare. Kader Posyandu mawar memberikan penyuluhan perilaku hidup bersih dan sehat.

4. Gizi. Kader Posyandu Mawar memberikan makanan sehat untuk bayi dan balita setiap kegiatan penimbangan bayi/balita.

Manfaat yang diperoleh kader posyandu dalam melaksanakan kegiatan di Posyandu Brigade Infanteri 15 Kujang II Cimahi diantaranya:

1. Kader posyandu merasa percaya diri dalam lingkungan sosialnya.

2. Kader mempunyai banyak teman (sosialisasinya baik).

3. Kader menjadi lebih mandiri dan disiplin.

4. Kadermerasaterhormatbisabergabungsebagai kaderPosyandusehinggasosialisasidenganwarg aasramalebihdekat.
5. Kaderjugamerasabertambahpengetahuannyaten tangkesehatandasarbagiibudananak.

Diharapkan kader Posyandu Mawar untuk lebih meningkatkan lagi pengetahuan tentang kesehatan dasar bayi dan balita melalui kegiatan pelatihanpelatihan. Kerjasama dengan pemerintah ditingkatkan, yaitu dengan petugas puskesmas agar semua kegiatan posyandu bisa dilaksanakan.

\section{E. DAFTAR PUSTAKA}

Departemen Kesehatan RI, 2006, Pedoman Umum Pengelolaan Posyandu, Departemen Kesehatan, Jakarta.

Ghony, M. Djunaidi \& Almanshur, Fauzan. 2012. Metode Penelitian Kualitatif. Yogyakarta. ArRuzz Media.

Mulyana, Enceng. 2008. Model Tukar Belajar (Learning Exchange) dalam Perspektif Pendidikan Luar Sekolah. Bandung. Alfabeta.

Mulyana dkk. 2005. Model Pemberdayaan Pemuda Melalui KUPP Berbasis Pertanian Holtikultura. Direktorat Jenderal Pendidikan Luar Sekolah. (BP-PLSP) Regional II Jayagiri.

Sembiring, N, 2004, Posyandu Sebagai Saran Peran Serta Masyarakat Dalam Usaha peningkatan Kesehatan Masyarakat, USU Digital Library

Sobahi, Karna \& Suhana, Cucu, 2011, Pemberdayaan Masyarakat Dalam Pendidikan di Era Otonomi Daerah, Cv Cakra, Bandung.

Sugiyono. 2013. MetodePenelitianKuantitatif, Kualitatif, Dan R\&D. Bandung.Alfabeta.

Taneko, Sulaeman B, 1986, Konsepsi Sistem Sosial Dan Sistem Sosial Indonesia, CV Fajar Agung, Jakarta 